\title{
Isolated aniridia
}

INSERM

\section{Source}

INSERM. (1999). Orphanet: an online rare disease and orphan drug data base. Isolated aniridia. ORPHA:250923

Isolated aniridia is a congenital bilateral ocular malformation characterized by the complete or partial absence of the iris. 